\title{
Teamwork Effectiveness in Student's Final Year Project
}

\author{
https://doi.org/10.3991/ijet.v16i15.23705 \\ Norazah Yusof ${ }^{\bowtie}$, Ramlah Hussein, Rathiah Hashim, Andi Besse Firdausiah Mansur, \\ Saadia Malik, Nada Bajnaid, Shereena Mohd Arif \\ King AbdulAziz University, Kingdom of Saudi Arabia \\ nyusof@kau.edu.sa
}

\begin{abstract}
The goal of this paper is to deliberate issues pertaining to teamwork effectiveness among students in a university environment. Final year project is an important assessment to measure students' teamwork skills in the university. Three main factors have been identified that contribute to teamwork effectiveness. The factors are namely interpersonal skills, interdependence and commitment to success. Interpersonal factors include social sensitivity and emotional engagement attributes. In this perspective, measures such as teamwork support, care, trust, honesty and respect towards team members are important key criteria. On the other hand, interdependence among others includes traits such as promoting each other to achieve common goals, bringing the best of each other and helping each other completing the task. Commitment to team success involves high obligation, high motivation, strong common goals and strong shared values and beliefs. In this paper, construct items for each factor are developed based on previous studies. The findings show that these factors are relevant toward the success of the student's final year project. Lacking these skills may result in poor performance among team members and may lead to unfavorable outcome.
\end{abstract}

Keywords - teamwork effectiveness, interpersonal skills, interdependence, commitment to success

\section{Introduction}

Final year projects are essential course to be taken by all university students in their Bachelor degree program. It is an intensive, active learning experience requiring significant effort in planning and implementation, and in certain program they are required to work in team. Students deliver the results of their experience in a final written report and oral presentation. While performing the project, students are expected to integrate ideas and knowledge acquired from several topics they have studied and the course material. Through the student project, students have the opportunity to develop and improve many soft skills, such as the communication, teamwork, leadership, professional, interpersonal, intrapersonal, interdependence and ethics skills [1]- [5]. Among these soft skills, teamwork is identified as one of the most valued and important skills among graduate students [6]- [8]. 
A team can be described as a set of people with individual skills required to complete tasks or project, in which each team member has common goals, operates with a high degree of interdependence, shares responsibility and is accountable for the collective performance [2] [9]. Teamwork is the process of individuals performing activities jointly in a supportive situation through sharing knowledge and skills in order to achieve common goals [8] [10]. There are several theories related to teamwork. Among them are the Bruce Tuckman of Team Stages [11], Belbin's Theory of Team Roles [12] and Tajfel's Theory on Social Identity [13].

In addition, many educational Universities represented by Association of American Colleges and Universities National Leadership Council (AACU) and Accreditation Board for Engineering and Technology (ABET), identify teamwork as a necessary skill among college graduates in order to prepare them for success in life, especially in the workplace [6]. A survey conducted by the National Association of Colleges and Employers (NACE) in 2015 has revealed that "Ability to work in a team structure" is an extremely important skill with 5-point scale. In all majoring and degrees, employers are seeking graduates who are able to work well in teams and who are decisive problem solvers [7]. Moreover, researchers reveal that projects done collaboratively have given positive impact on student development [8] [14]- [16]. Tarricone and Luca also agreed that effective team work was an essential ingredient in the success of the students completing their project-based unit [10].

Interpersonal skills in teamwork involves two factors, namely social sensitivity [5] [17] and emotional engagement [3] [18] [19]. Social sensitivity is the individual skill to perceive and understand the feeling of others [20]. Teams with high level of social sensitivity tend to perform well in team work task activities [20]. The interpersonal skill factors also include the ability to share and resolve any evolving issues with team members, that promote honesty, trustworthiness, support, respect, and commitment to the team and the team members [5] [12]. Other than that, encouraging a caring work environment is important, including the ability to work effectively, as well as to protect and support each other.

A team displaying good interdependence promotes the other team members to achieve their common goal, start supporting one another, and make contributions toward the whole [2] [10] [21]. In a study conducted by Aziz et al. [22], task interdependence positively moderates the performance at team level. It motivates team members to increase their ability to cooperate and maintain efficient teamwork. The team comes to realize that every member is important in achieving their common goals and they become dependent and committed to their members [23].

High commitment from each team member to work effectively is an essential factor in team success [24]. Successful teams have high motivation, are engaged and are strongly determined to achieve common goal at the highest level. Some previous study has shown that commitment to team goals is capable of augmenting the level of task outcome when it comes to difficult goal [25]- [27]. The other study conducted by Hyatt and Ruddy [28] mentioned that there is correlation among group aim assurance and parameter toward quantification of goal accomplishment.

In this regard, the final year student project shall be conducted in teams to provide students with growth in teamwork skills [4] [7]. However, without proper awareness 
on how to construct good teamwork, students may face various problems associated with the operational activities of teams, as well as interaction among the team members [29]. The misconception of teamwork as a group work, where the work was divided equally among team members and to be performed individually, may lead to unsuccessful and ineffective outcome. And the phenomena of free riding, social loafing and conflict within teams are the adverse effects on student motivation when working in a team [30].

Apart from the students' negative attitude, the institution's education system, which recognizes individual work, could appear to be against placing students in teams. It may result in backlash, when the system implements a universal grading scheme, despite the fact that the team members may not have contributed equally [29].

This paper focuses on three key factors that contribute to teamwork effectiveness, namely interpersonal skills, interdependence and commitment to team success. This study reviews on the successful attributes needed for effective teamwork and conduct a pilot study to identify that these key factors need to be carefully considered by the students as well as the supervisors.

\section{Final year project at the faculty of computing and information technology}

The Faculty of Computing and Information Technology at King Abdul Aziz University in Rabigh (FCITR) offers three major programs that are based on the department, namely Computer Science (CS), Information Technology (IT), and Information Systems (IS). These programs are accredited by the Accreditation Board for Engineering and Technology (ABET) in which the graduates of the program should acquire five abilities of ABET criterion-3 as shown in Table 1 [31].

Table 1. ABET Criterion-3

\begin{tabular}{|c|l|}
\hline $\begin{array}{c}\text { Student } \\
\text { Outcome }\end{array}$ & \multicolumn{1}{c|}{ Description } \\
\hline 1 & $\begin{array}{l}\text { Analyse a complex computing problem and to apply principles of computing and other relevant } \\
\text { disciplines to identify solutions. }\end{array}$ \\
\hline 2 & $\begin{array}{l}\text { Design, implement, and evaluate a computing-based solution to meet a given set of computing re- } \\
\text { quirements in the context of the program's discipline. }\end{array}$ \\
\hline 3 & Communicate effectively in a variety of professional contexts. \\
\hline 4 & $\begin{array}{l}\text { Recognize professional responsibilities and make informed judgments in computing practice } \\
\text { based on legal and ethical principles. }\end{array}$ \\
\hline 5 & $\begin{array}{l}\text { Function effectively as a member or leader of a team engaged in activities appropriate to the } \\
\text { program's discipline. }\end{array}$ \\
\hline
\end{tabular}

To graduate, the students are required to take two capstone courses with the code 498 and 499. These two courses are referred to as the final year project that ties together the theoretical concepts of their program to solving practical problem as a team-oriented project. Each team can consist of two to five members [32], and is assigned a project supervisor. 
The project supervisor is responsible to guide and motivate the students while implementing the project, provide advice on how to plan and carry out investigations and analyse data, as well as highlight knowledge, skills and accessibility of the tools needed for the project. There are weekly meeting and the supervisor continuously observes and monitors the students' progress.

The 498 course aims to meet the student outcomes 1, 2, 3, 4, and 5 of ABET criterion-3, while the 499 course aims to meet the student outcome 2, 3, 4, and 5 of ABET criterion-3 (see Table 1). In 498, the students are expected to propose, analyse, and design a software system, and conduct a thorough investigation of their particular program related problem for industry/research-based project. At the end of the 498 session, the students are required to deliver oral presentation, submit the weekly progress reports, and the proposal report for the project.

Further, in 499, the students continue the System/Research development of the project and produce the complete software or system. And at the end of the session, the students are required to deliver oral presentation, submit the weekly progress reports for that session, a final report for the project, as well as to demonstrate the software product.

The assessments of both 498 and 499 involve the project supervisor, examination committee, and peers. Each student is evaluated individually and as a team. The peer evaluations allow each student to evaluate other members in the team [33]. Peer evaluations are helpful in developing student's judgement skills by encouraging them to reflect their contributions to the group work, as well as their peers' contributions [34]. The evaluation shall be done with complete privacy and finally handed over to the project supervisor at the end of the session. Each team member will give a scale between $0-5$ on commitment, contributions, participation, supportive attitudes and trust of the team member for the team work assessment, which is in criteria 5 of the Student Outcome as shown in Table 1. To avoid team bias, the assessment score for the peer evaluation is $30 \%$, while the supervisor evaluation takes $70 \%$ of the total score for this team work assessment [35] [36].

This paper focuses only on the student outcome 5 of the ABET criteria stated in Table 1, that is to determine the student's ability to function effectively as a member or leader of a team engaged in activities appropriate to the program's discipline. This study aims to identify the key factors that lead towards a successful team.

\section{$3 \quad$ Method}

\subsection{Research method}

This study employs quantitative research method for both data collection and data analysis processes. A survey was carried out at the female section of the Faculty of Computing and Information Technology, King Abdul Aziz University in Rabigh (FCITR). The objective of this study is to investigate on the important factors that lead towards a successful team. 


\subsection{Participant}

In this study, a total number of 42 female students were involved. They were the undergraduate students who registered 498 and 499 courses for their final year project in the year 2017 and 2018. These students are from three different departments, namely the Information Systems (IS), the Computer Science (CS), and the Information Technology (IT).

Out of the total 42 respondents, this study consisted of 8 IS students (19\%), 16 CS students (38.1\%) and 18 IT students (42.9\%). The number of sample is small due to the small number of female students enrolled in each course of the department.

\subsection{Research instrument}

In this study, the student's department and gender were assessed as the demographic questionnaire. To probe the participants' perceptions about working in team during conducting their final year project, the key attributes for successful teamwork by Tarricone and Luca [10] were adapted as the primary instrument of interest. The original version of Tarricone and Luca, consisted of 53 items and were divided into 6 key attributes.

However, this study only adapted 15 items and focused on 3 key attributes. The first 4 items were grouped under Interpersonal skills, 6 items under the Interdependence and 5 items under Commitment to team success. These items were posed as statements, with possible responses on a 5-point Likert-type scale of Strongly Disagree (1), Disagree (2), Neutral (3), Agree (4) and Strongly Agree (5).

To help respondents who might face difficulties in understanding foreign language, the survey questions were translated from English language into Arabic language. These questionnaires were then posted to the respondents through the Google forms.

\subsection{Data analysis}

The data were analysed using IBM SPSS 25 . From the reliability test conducted, the Cronbach's alpha values ranged from 0.81 to 0.88 as shown in Table 2. The results show that the constructs used in this study are reliable and are appropriate to perform further analysis on the data investigated.

Table 2. Cronbach Alpha for each construct

\begin{tabular}{|l|c|c|}
\hline \multicolumn{1}{|c|}{ Construct } & Items in Scale & Cronbach Alpha \\
\hline Interpersonal Skill & 4 & 0.86 \\
\hline Interdependence & 6 & 0.81 \\
\hline Commitment to team success & 5 & 0.88 \\
\hline
\end{tabular}

\section{$4 \quad$ Results and discussion}

Table 3 exhibits the distribution of the useful factors that contribute to successful teamwork. The teamwork successful factors had means ranging between 4.44 and 
4.55. In general, the respondents seemed to agree to the statements in the questionnaire. From the responses in Table 3, it can be seen that the Interpersonal Skills is one of the essential key factor in ensuring the success of the teamwork.

Table 3. Successful teamwork

\begin{tabular}{|c|c|c|c|c|}
\hline \multirow[b]{2}{*}{ Construct } & \multirow{2}{*}{$\begin{array}{c}\mathrm{N} \\
\text { Statistic }\end{array}$} & \multicolumn{2}{|c|}{ Mean } & \multirow{2}{*}{$\begin{array}{c}\text { Standard deviation } \\
\text { Statistic }\end{array}$} \\
\hline & & Statistic & $\begin{array}{l}\text { Standard } \\
\text { error }\end{array}$ & \\
\hline Interpersonal Skill & 42 & 4.55 & .08 & .54 \\
\hline Interdependence & 42 & 4.44 & .09 & .57 \\
\hline Commitment to team success & 42 & 4.45 & .09 & .57 \\
\hline
\end{tabular}

In response to the interpersonal skills dimension, respondents believe that members must be respectful and supportive of one another, and realistic in mutual expectations. Table 4 shows the highest mean value i.e. 4.60 for this item. Moreover, the respondents also agree that members must protect and support each other, must care for each other, as well as must respect and trust each other. Lacking of these interpersonal skills may lead to ineffective team working.

The interpersonal skills mentioned above are found to be consistent with previous studies [11] [12] [20]. Hence, the above skills are found relevant in teamwork success. Having these skills will promote positive outcomes to the team project as a whole.

Table 4. Interpersonal skills

\begin{tabular}{|c|c|c|c|c|}
\hline \multirow[b]{2}{*}{ Construct } & \multirow[b]{2}{*}{$\begin{array}{c}\mathbf{N} \\
\text { Statistic }\end{array}$} & \multicolumn{2}{|c|}{ Mean } & \multirow{2}{*}{$\begin{array}{l}\text { Standard } \\
\text { deviation } \\
\text { Statistic }\end{array}$} \\
\hline & & Statistic & $\begin{array}{c}\text { Standard } \\
\text { error }\end{array}$ & \\
\hline I believe that people must care for each other & 42 & 4.52 & .092 & .594 \\
\hline $\begin{array}{l}\text { I believe that members must protect and support } \\
\text { each other }\end{array}$ & 42 & 4.52 & .098 & .634 \\
\hline $\begin{array}{l}\text { I believe that members must be respectful and } \\
\text { supportive of one another, and realistic in mutual } \\
\text { expectations }\end{array}$ & 42 & 4.60 & .097 & .627 \\
\hline $\begin{array}{l}\text { I believe members must respect and trust each } \\
\text { other }\end{array}$ & 42 & 4.57 & .109 & .703 \\
\hline Valid N (listwise) & 42 & & & \\
\hline
\end{tabular}

Besides the Interpersonal skill, the Interdependence is also an essential trait to teamwork success. The detail descriptive statistics for this factor is illustrated in Table 5. The respondents agree that the team members must work together effectively to produce successful systems and they interact to help each other accomplish the task and promote one another's success.

In addition, the respondents also agree that team members must never be fully selfdirected or completely independent. Likewise, the team members must take an interest in both the group and each individual achievement. Together the group can deliver more than the individuals rather than do it in isolation. And the respondents believe that one cannot succeed unless the other members of the group succeed. 
Table 5. Interdependence skills

\begin{tabular}{|c|c|c|c|c|}
\hline \multirow[b]{2}{*}{ Construct } & \multirow{2}{*}{$\begin{array}{c}\mathrm{N} \\
\text { Statistic }\end{array}$} & \multicolumn{2}{|c|}{ Mean } & \multirow{2}{*}{$\begin{array}{c}\text { Standard } \\
\text { deviation } \\
\text { Statistic }\end{array}$} \\
\hline & & Statistic & $\begin{array}{l}\text { Standard } \\
\text { error }\end{array}$ & \\
\hline $\begin{array}{l}\text { One cannot succeed unless the other members } \\
\text { of the group succeed }\end{array}$ & 42 & 4.19 & .157 & 1.018 \\
\hline $\begin{array}{l}\text { Together the group can deliver more than the } \\
\text { individuals rather than do it in isolation }\end{array}$ & 42 & 4.26 & .132 & .857 \\
\hline $\begin{array}{l}\text { Team members must work together effective- } \\
\text { ly to produce successful systems }\end{array}$ & 42 & 4.64 & .095 & .618 \\
\hline $\begin{array}{l}\text { Team members interact to help each other } \\
\text { accomplish the task and promote one anoth- } \\
\text { er's success }\end{array}$ & 42 & 4.57 & .109 & .703 \\
\hline $\begin{array}{l}\text { Team members must take an interest in both } \\
\text { the group and each individuals achievement }\end{array}$ & 42 & 4.40 & .132 & .857 \\
\hline $\begin{array}{l}\text { Team members must never be fully self- } \\
\text { directed or completely independent }\end{array}$ & 42 & 4.55 & .103 & .670 \\
\hline Valid N (listwise) & 42 & & & \\
\hline
\end{tabular}

In addition, the Commitment to Team Success is another key factor to the effectiveness of teamwork. In Table 6, the respondents agree that understand the purpose of the project and its objectives, as well as the need for a strong team commitment, are important factors in order to succeed. Moreover, the respondents agree to believe that all members must share a strong common goal and must be committed and satisfied with their work. The respondents also agree that in order to succeed all members must have strong shared values and beliefs. Without Commitment to Team Success, the teamwork may have disturbing outcome.

Table 6. Commitment to team success skills

\begin{tabular}{|l|c|c|c|c|}
\hline \multicolumn{1}{|c|}{ Construct } & \multirow{2}{*}{$\begin{array}{c}\text { N } \\
\text { Statistic }\end{array}$} & Statistic & $\begin{array}{c}\text { Standard } \\
\text { error }\end{array}$ & $\begin{array}{c}\text { Standard } \\
\text { deviation } \\
\text { Statistic }\end{array}$ \\
\hline $\begin{array}{l}\text { I understand the purpose of this } \\
\text { project and its objectives }\end{array}$ & 42 & 4.57 & .097 & .630 \\
\hline $\begin{array}{l}\text { I believe all members must share a } \\
\text { strong common goal }\end{array}$ & 42 & 4.55 & .103 & .670 \\
\hline $\begin{array}{l}\text { In order to succeed we need a strong } \\
\text { team commitment }\end{array}$ & 42 & 4.57 & .119 & .770 \\
\hline $\begin{array}{l}\text { In order to succeed all members must } \\
\text { have strong shared values and beliefs }\end{array}$ & 42 & 4.12 & .133 & .861 \\
\hline $\begin{array}{l}\text { I believe we must be committed and } \\
\text { satisfied with our work }\end{array}$ & 42 & 4.45 & .128 & .832 \\
\hline Valid N (listwise) & 42 & & & \\
\hline
\end{tabular}

The monitoring and evaluations of both 498 and 499 capstones courses are another important factors to support team effectiveness. These include the weekly meetings, group progress reports, the continuous supervisor evaluations, the final stage examination committee evaluations and the peer evaluations. 
From the weekly meetings and the weekly group progress reports, the supervisor able to observe the team's interpersonal skill, the interdependence and commitments to team success. The supervisor able to recognize the team with good interpersonal skill who acknowledged each member in the team as having different personalities and experienced problems at different stage. They possessed respects and supports for each other in difficult times. On the other hand, the team having lack of interpersonal skills expressed little concern for each other and offered no support for others in difficult times. When this kind of situation occurred, the supervisor should handle the conflict by requesting them to respect and support each other [5].

In addition, interdependent team members demonstrated their responsibilities to other team members and they were able to complete their tasks on time. They believed that the contribution of every team member in this project was the key to success. On the other hand, no interdependence between team members can be identified when team members were only focused on their own tasks and were not willing to help others. This results in a lack of team unity and cooperation, and can result in teams splitting up. Before this situation getting worst, the supervisor should take necessary actions by motivating each team members to cooperate and encourage them to maintain efficient teamwork [22].

Further, supervisor may be able to notice a positive commitment to team success, by observing teams that had highly focused on delivering quality product and not preoccupied with personal issues that might interrupted their objectives. On the other hand, there were mismatched of expectations between team members. For example, one member might be highly motivated to achieve a high quality product, but the other members were merely just gaining a pass and only put in minimum effort. This situation caused frustration and a lot of problems with the team. The supervisor may overcome this issue by letting each team member knows the project expectation clearly and simply. The supervisor may encourage discussions among team so that the less engaged member to understand what's required of them.

The continuous supervisor evaluations and the final stage examination committee evaluations are done on each student individually and as a team. During the final oral presentations and project demonstrations, the examination committee able to measure the interdependency and commitment to team success of each team.

The peer evaluation allows students to evaluate their team members individually. It is a good platform to be applied in interdependence and commitment to team success issues. The team member had a chance justify and to rate when there were members who were not performing or only put minimal effort in the project.

These monitoring and evaluations exercises are in line by previous works [5] [10] [17]- [19] [22] [25]- [28] [35] and [36].

\section{Conclusion}

This paper focused on three useful factors that contributed to the success of teamwork in Final Year project at the Faculty of Computing and Information Technology in King AbdulAziz University, in which team working is considered as one of the 
assessment criteria of student outcome according to ABET. The three useful factors are Interpersonal skill, Interdependence, and Commitment to team success. From the analysis, it is clear that being respectful and supportive of one another, and also being realistic in mutual expectations, are viewed as crucial. By possessing the interpersonal skills, the team members showed consideration for each other in good or difficult times.

These main factors need to be seriously reflected by the students and the supervisors. Lacking in any of these skills may result in students facing various problems associated with the operational activities of teams, as well as poor performance among team members that may lead to unsuccessful outcome.

For future work, this research may explore other key factors that support teamwork effectiveness, such as leadership, commitment to team process, open communication and positive feedback. It will be interesting to further explore the correlations among these factors to determine the strong attributes that contribute significantly to teamwork success. By determining all the key success factors, this research may provide proper awareness and guidelines to both students and instructors on how to construct effective teamwork.

\section{Acknowledgment}

This work is supported by King Abdulaziz University. The authors would like to thank the Deanship of Scientific Research Management (DSR) King Abdulaziz University for the support and incentive extended in making this study a success.

\section{$7 \quad$ References}

[1] Martins, J., Duarte, M., Cunha, S., Almada-Lobo, B., Marques, A. T. and Magalhães, B. (2007). "The role of hard and soft skills on engineering education," Eng. Educ., no. May 2014, pp. 3-8.

[2] Chatwattana P. and Nilsook, P. (2017). "A Web-based Learning System using Projectbased Learning and Imagineering”. International Journal Of Emerging Technologies In Learning (IJET), 12(05), pp. 4-22. https://doi.org/10.3991/ijet.v12i05.6344

[3] Pentland, A. S. (2020). "The new science of building great teams," Harv. Bus. Rev., vol. 90, no. 4, pp. 60-69, 2012, Accessed: Sep. 12, 2020. [Online]. Available: https://ci.nii.ac.jp/naid/20001077629.

[4] Uziak, J. "Position of the final year project in an engineering curriculum," in Global Journal of Engineering Education, vol. 17, no. 3, pp. 113-118, 2015.

[5] Bennett, L. M., Levine-Finley, S. and Gadlin, H. Collaboration Team Science: Field Guide, US Department of Health \& Human Services, National Institutes of Health, National Cancer Institute, 2018.

[6] Hughes R. L. and Jones, S. K. (2011). "Developing and assessing college student teamwork skills," New Dir. Institutional Res., vol. 2011, no. 149, pp. 53-64, Mar. 2011. https://doi.org/10.1002/ir.380

[7] Adams, S. (2014). "The 10 Skills Employers Most Want in 20-Something Employees," Forbes, pp. 10-12, [Online]. Available: http://www.forbes.com/sites/susanadams/2013/10/ 
11/the-10-skills-employers-most-want-in-20-somethingemployees/\%5Cnhttp://www.forbes.com/sites/susanadams/2014/11/12/the-10-skillsemployers-most-want-in-2015-graduates/

[8] Gherib T. and Bouhadada, T. (2021). "Towards a New Platform Based on Web 2.0 Technologies Supporting Collaborative Clinical Reasoning Behavior Skills," International Journal of Emerging Technologies in Learning (iJET), 16(08), pp. 106-131, https://doi.org/10.3991/ijet.v16i08.19471

[9] Morgeson, F. P., Lindoerfer, D. and Loring, D. J. (2010). "Developing team leadership capability," The Center for Creative Leadership Handbook of Leadership Development. pp. 285-312.

[10] Tarricone P. and Luca, J. (2002). "Successful teamwork: A case study," in Quality Conversations, Proceedings of the 25th HERDSA Annual Conference, Perth, Western Australia.

[11] Tuckman, B. W. (1965). "Developmental sequence in small groups," Psychol. Bull., vol. 63, no. 6, pp. 384-399, doi: 10.1037/h0022100

[12] Belbin, R. M. (2011). "Management Teams: Why They Succeed or Fail (3rd ed.)," Hum. Resour. Manag. Int. Dig., vol. 19, no. 3, pp. 171-175. https://doi.org/10.1108/hrmid. 2011.04419cae. 002

[13] Tajfel, H., Turner, J.C., Austin, W.G. and Worchel, S. (1979). "An integrative theory of intergroup conflict," Organizational identity: A reader, vol. 56, p. 65.

[14] Clark, N., Davies, P. and Skeers, R. (2005). "Self and peer assessment in software engineering projects," Conf. Res. Pract. Inf. Technol. Ser., vol. 42, no., pp. 91-100, 2005

[15] Kuh, G. D. (2008). "Excerpt from high-impact educational practices: What they are, who has access to them, and why they matter," Association of American Colleges and Universities, vol. 14 , no. 3 , pp. $28--29$.

[16] Neumann, P., Kowitz, C., Schranner, F. and Azarnykh, D. "Interdisciplinary teamwork in HPC education: Challenges, concepts, and outcomes," J. Parallel Distrib. Comput., vol. 105, pp. 83-91, Jul. 2017. https://doi.org/10.1016/j.jpdc.2016.12.025

[17] Woolley, A. W. Chabris, C. F., Pentland, A., Hashmi, N. and Malone, T. W. "Evidence for a collective intelligence factor in the performance of human groups," Science (80-.), vol. 330, no. 6004, pp. 686-688, Oct. 2010. https://doi.org/10.1126/science.1193147

[18] Stokols, D., Misra, S., Moser, R. P., Hall, K. L. and Taylor, B. K. (2008). "The Ecology of Team Science. Understanding Contextual Influences on Transdisciplinary Collaboration," American Journal of Preventive Medicine, vol. 35, no. 2 SUPPL. Elsevier, pp. S96-S115. https://doi.org/10.1016/i.amepre.2008.05.003

[19] Parker J. N. and Hackett, E. J. (2012). "Hot spots and hot moments in scientific collaborations and social movements," Am. Sociol. Rev., vol. 77, no. 1, pp. 21-44. https://doi.org/ $\underline{10.1177 / 0003122411433763}$

[20] Bender, L., Walia, G., Kambhampaty, K., Nygard, K. E. and Nygard, T. E. "Social sensitivity correlations with the effectiveness of team process performance," in Proceedings of the ninth annual international conference on International computing education research ICER '12, 2012, p. 39. https://doi.org/10.1145/2361276.2361285

[21] Kuthyola, K. F., Liu, J. Y. C. and Klein, G. (2017). "Influence of task interdependence on teamwork quality and project performance," in Lecture Notes in Business Information Processing, vol. 288, pp. 135-148. https://doi.org/10.1007/978-3-319-59336-4 10

[22] Aziz, A., Ahmed, F., Aziz, M. F., Fayyaz, M. and Abid, N. (2019).“Impact of Emotional Intelligence on Individual and Project Team Performance in Information Technology Projects Under the Moderating Role of Task Interdependence," J. Secur. Stud. Glob. Polit., vol. 4, no. 1, p. 1. https://doi.org/10.33865/jssgp.004.01.0179 
[23] Nunamaker, J. F., Briggs R. O. and Romano, N. C. (2015). Collaboration Systems: Concept, Value, and Use.vol. 19, Routledge.

[24] Strauss, K., Griffin, M. A. and Rafferty, A. E. (2009). "Proactivity directed toward the team and organization: The role of leadership, commitment and role-breadth selfefficacy," Br. J. Manag., vol. 20, no. 3, pp. 279-291. https://doi.org/10.1111/j.1467$\underline{8551.2008 .00590 . \mathrm{x}}$

[25] Klein H. J. and Mulvey, P. W. (1995). "Two investigations of the relationships among group goals, goal commitment, cohesion, and performance," Organ. Behav. Hum. Decis. Process., vol. 61, no. 1, pp. 44-53. https://doi.org/10.1006/obhd.1995.1004

[26] Klein H. J. and Kim, J. S. (1998). "A field study of the influence of situational constraints leader-member exchange, and goal commitment on performance," Academy of Management Journal, vol. 41, no. 1, pp. 88-95. https://doi.org/10.5465/256900

[27] Resick C. J. and Bloom, A. J. (1997). "Effects of goal setting on goal commitment, team processes, and performance," Psychology and Education.

[28] Hyatt D.E. and Ruddy, T. M. (1997). "An examination of the relationship between work group characteristics and performance: Once more into the breech," Personnel Psychology, vol. 50, no. 3, pp. 553-558. https://doi.org/10.1111/j.1744-6570.1997.tb00703.x

[29] Volkov A. and Volkov, M. (2007). "Teamwork and Assessment: a critique," E-Journal of Business Education I\& Scholarship of Teaching, vol. 1, no. 1, pp. 59--64.

[30] Hall D. and Buzwell, S. (2013). "The problem of free-riding in group projects: Looking beyond social loafing as reason for non-contribution," Act. Learn. High. Educ., vol. 14, no. 1, pp. 37-49. https://doi.org/10.1177/1469787412467123

[31] ABET Computing Accreditation Commission, (2020). Criteria for Accrediting Computing Programs, 2019 - $2020 \mid$ ABET, 2018. Accessed on: [Online]. Available: https://www.abet.org/accreditation/accreditation-criteria/criteria-for-accreditingcomputing-programs-2019-2020/

[32] Al Mulhim E. and Eldokhny A. (2020) "The impact of collaborative group size on students' achievement and product quality in project-based learning environments," International Journal of Emerging Technologies in Learning (iJET), 15(10), pp. 157-174. https://doi.org/10.3991/ijet.v15i10.12913

[33] Jones A. and Birtle, M. "Individual assessment technique for group projects in software engineering," Softw. Eng. J., vol. 4, no. 4, pp. 226-232, 1989. https://doi.org/10.1049/sej.1989.0029

[34] Planas-Lladó A. et al., (2018). "Using peer assessment to evaluate teamwork from a multidisciplinary perspective,” Assess. Eval. High. Educ., vol. 43, no. 1, pp. 14-30, doi: 10.1080/02602938.2016.1274369.

[35] Raban R. and Litchfield, A. (2007). "Supporting peer assessment of individual contributions in groupwork," Australasian Journal of Educational Technology, vol. 23, no. 1, 2007. https://doi.org/10.14742/ajet.1272

[36] Zheng, L., Chen, N. S., Cui, P. and Zhang, X. "A systematic review of technologysupported peer assessment research: An activity theory approach," Int. Rev. Res. Open Distance Learn., vol. 20, no. 5, pp. 168-191, 2019, doi: 10.19173/irrodl.v20i5.4333.

\section{Authors}

Norazah Yusof is an Associate Professor in Computer Science department at the King Abdul Aziz University. She is a member of the Institute of Electrical and Electronics Engineers (IEEE) and a member of the Society of Engineering Education 
Malaysia (SEEM). Her research interests include Learning Analytics, Soft Computing, Teamwork effectiveness, and Software Engineering

Ramlah Hussein is a freelance research associate, author and consultant in the Information Systems field. Her research interest covers an interdisciplinary area including internet privacy, information security, e-government, online learning and technology acceptance. She had served as an associate professor at both the public and private institutions in Malaysia and Saudi Arabia.

Rathiah Hashim works at the department of Information Technology, the King Abdul Aziz University. Her research areas include Visual Data, Human Computer Interface, Applied Psychology and Computer Graphics.

Andi Besse Firdausiah Mansur is an Assistant Professor in Computer Science Department at the King Abdul Aziz University. Her research interests are Social Network Analysis, E-learning, Clustering, Data Mining and Mathematics.

Saadia Malik is an Assistant Professor in the Information Systems department of King Abdul Aziz university. Her research interests include Artificial Intelligence, Data Mining, Information Retrieval and Statistical Analysis.

Nada Bajnaid is an Assistant Professor at King Abdul Aziz University. Her research interests are Ontology, Semantic Web, Context Awareness and software quality.

Shereena Mohd Arif was an Assistant Professor in Information Science department at the King Abdul Aziz University. She was a member of the Institute of Electrical and Electronics Engineers (IEEE). Her research interests include Learning Analytics, Data Retrieval and Information Science. She is now retired and spend her time doing voluntary community work in Qatar.

Article submitted 2021-05-03. Resubmitted 2021-06-05. Final acceptance 2021-06-05. Final version published as submitted by the authors. 